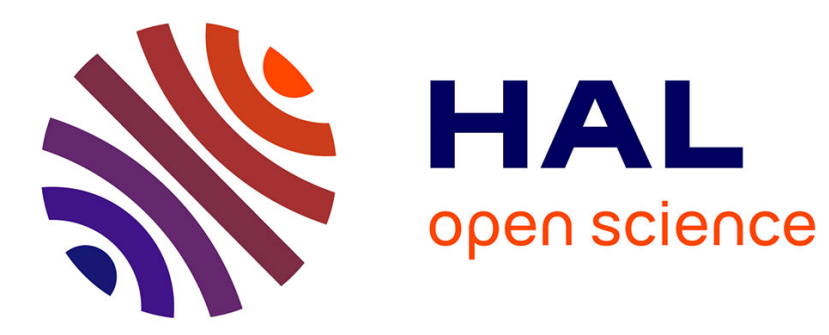

\title{
Dairy Policy in Senegal: the Need to Overcome a Technical Mindset
}

Sergio Dario Magnani, Véronique Ancey, Bernard Hubert

\section{To cite this version:}

Sergio Dario Magnani, Véronique Ancey, Bernard Hubert. Dairy Policy in Senegal: the Need to Overcome a Technical Mindset. European Journal of Development Research, 2019, 31 (5), pp.12271245. 10.1057/s41287-019-00208-4 . hal-03188274

\section{HAL Id: hal-03188274 https://hal.science/hal-03188274}

Submitted on 2 Apr 2021

HAL is a multi-disciplinary open access archive for the deposit and dissemination of scientific research documents, whether they are published or not. The documents may come from teaching and research institutions in France or abroad, or from public or private research centers.
L'archive ouverte pluridisciplinaire HAL, est destinée au dépôt et à la diffusion de documents scientifiques de niveau recherche, publiés ou non, émanant des établissements d'enseignement et de recherche français ou étrangers, des laboratoires publics ou privés. 


\title{
Dairy Policy in Senegal: the Need to Overcome a Technical Mindset
}

\begin{abstract}
Since the 1970s, the import of tax-free powdered milk has presented an easy solution to the growing demand for dairy products in West Africa. Recent increases in agricultural price volatility have since contributed to a renewed interest in local milk. However, while the present situation raises issues of food security, rural development and trade policy, public policy remains overly focused on the technical dimensions of dairy development. This article presents the dairy landscape of Senegal, a major regional importer of powdered milk, by considering development dynamics in light of the interactions between technical and organizational models and livestock systems, in terms of relationships with resources and environment, knowledge and social organization. Two implications are discussed: the need for effective sectoral policy to tip the balance in favour of local milk; the need to base public action on a better understanding of, and improved support for, livestock systems in all their diversity.
\end{abstract}

Keywords: Dairy policy, Public policy, Development Anthropology, Pastoralism, Intensification, Technical changes, Senegal, West Africa.

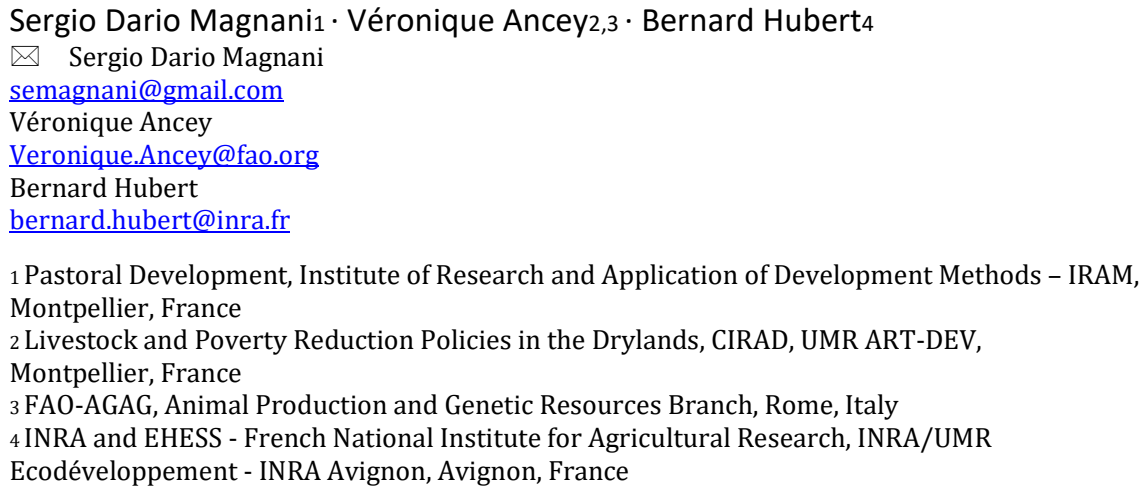

${ }_{1}$ Pastoral Development, Institute of Research and Application of Development Methods - IRAM,

Montpellier, France

2 Livestock and Poverty Reduction Policies in the Drylands, CIRAD, UMR ART-DEV,

Montpellier, France

3 FAO-AGAG, Animal Production and Genetic Resources Branch, Rome, Italy

4 INRA and EHESS - French National Institute for Agricultural Research, INRA/UMR

Ecodéveloppement - INRA Avignon, Avignon, France

\section{Introduction}

Since the 1970s, the import of tax-free powdered milk has presented an easy solution to meet the growing urban demand for dairy products in Senegal. However, increasing agricultural commodity price volatility, which has been particularly strong over the last decade (OCDE/FAO, 2017), has shown the limits of this strategy. Faced with unstable powdered milk prices and the rapid growth of urban demand, national authorities and private dairy businesses have shown a renewed interest in local milk production. The primary concerns of the authorities are over macroeconomic imbalances, rural poverty and the urban population's access to dairy products. Private businesses have sought to position themselves in these promising markets through takeovers and partnerships (Choplin, 2016; CTA Agritrade, 2014; Hansel and Goodison, 2015; Orasmaa et al., 2016). In the last ten years, several dairy businesses have included local milk in their production in order to promote a positive business image, diversify their supply sources and generate more value-added products (Corniaux, 2015). 
In Senegal, this trend has reinforced a classical "technicist" approach which seeks to drive dairy development by using animal production science to intensify production systems, notably by promoting the systematic use of feeding inputs and a genetic improvement of cattle breeds. This model entails measures that reduce interactions between livestock systems and the environment, such as the settlement of herders, fodder crop development, the stabling of dairy cows and the adoption of specialized breeds. Far from being neutral, livestock production intensification has a long and controversial history in the Sahel, where it has been at the heart of a technoscientific paradigm that has shaped interventions in pastoral development since colonial times (Behnke and Scoones, 1993; Ellis and Swift, 1988; Homewood, 2008; Scoones, 1994).

While the technical dimensions of dairy production take center stage in public policy, the broader political and economic context, as well as the historical trends of sectoral public action, are the subject of little debate. Dairy development in Senegal has been characterized by limited, discontinuous public interventions, a disconnect between local production systems and technical models and contradictions between trade and development policies.

This article discusses the limits of a dairy development policy centered on technical issues. What are the implications of focusing on technical issues and productivity? What other political, economic and social dimensions are overlooked in this process? In what respect does this "technicist" approach constitute an obstacle to the conception and implementation of a more integrated sectoral policy?

This article comprises two parts: firstly, a synthetic overview of the historical trends in dairy development in Senegal from independence to the present day, in the broader and evolving political and economic context. Secondly, an analysis of three case studies reflecting different dairy development models and successive forms of public action in dairy production and collection. The first case study relates to intensive dairy farms operating in the peri-urban area of the capital Dakar. The second presents the dairy basin around the secondary city of Kolda in the southern region of Casamance, where a dozen mini-dairies collect the milk produced by agro-pastoralists. The third describes a new social business model set up by an industrial dairy in the Senegal River Valley in the north of the country, which relies on both powdered and fresh milk. The dairy processes local milk collected from hundreds of pastoralists within the area surrounding the city of Richard Toll. 


\section{Methodology}

From a methodological point of view, we regard the diversity of these case studies as an asset, demonstrating how dimensions beyond the technical sphere can be central to the trajectory of dairy development interventions in Senegal. Furthermore, we hold that the combined analysis of case studies and historical patterns of development provides useful insights to help to develop an effective dairy policy at both national and regional levels.

This research, which was conducted a part of a doctoral research project in development anthropology (Magnani, 2016), is grounded in the social sciences and adopts an interdisciplinary framework that considers how natural and living resources acquire different meanings and values for stakeholders (Hubert and Ison, 2011). Changes in food and development public policy touch on socio-economic issues (Binet, 2014; Gabas and al., 2014). The research was carried out in a collective research program on agroecology and livestock production in France, Brazil, Uruguay and Senegal ${ }^{1}$. Fieldwork was conducted in Senegal over three years (from May to June 2011; from June to November 2012; and from June to December 2013), drawing on standard qualitative methods from anthropology (participant observation, open interviews, analysis of local written sources). National livestock and dairy development policies were examined through interviews with public servants, development experts, researchers, leaders of livestock professional bodies, pastoralists and herders, and non-governmental organization workers. Dairy development dynamics were thus explored in the three areas mentioned above.

\section{Historical trends in dairy development public action in Senegal} The post-independence period (1960-1985): the failure of state intervention and the growth of powdered milk

After independence, Senegal inherited a segmented market with, on one hand, powder-based or imported dairy products for the expatriate population and, on the other, local milk and derived products historically traded locally or through mid- and long-range trade channels (Vatin, 1996: 126-130).

\footnotetext{
${ }^{1}$ Mouve, funded by the French National Research Agency (ANR).
} 
The first attempts at dairy industrialization in Africa, at the end of the 1960s, sought to imitate the Indian Flood model. In order to accelerate industrial development and cooperative organization, donated powdered milk was to be sold in order to finance local milk value chains, which, it was hoped, would then have gradually replaced the imports. Whereas the model played a positive role in India, where it was supported by a political commitment to autonomy and dairy development, it was a relative failure in West Africa for both local and international reasons (Vatin, 1996). This was particularly true in Senegal, where a state-run dairy industry (UCOLAIT), set up in Saint-Louis, operated for only four years (1968-1972). Though local milk collection had achieved promising results (200 000 liters in 1971), major production and marketing failures, combined with bad management, led the dairy to bankruptcy (Vatin, 1996: 142-146).

In the 1970s, powdered milk imports increased sharply (from less than $50000 \mathrm{t}$ in 1973 to over $100000 \mathrm{t}$ in 1977; Duteurtre and Corniaux, 2013: 35), mainly because of demographic growth, urbanization and trade policy. In reaction to this trend, the Senegalese government implemented a seven-year dairy development project, Projet de Développement de la Production Laitière intensive et semi-intensive dans la région des Niayes (Project for intensive and semi-intensive dairy development in the Niayes region, 1982-1989), in the countryside around the capital Dakar. The project, run by the Institut Sénégalais de Recherches Agricoles (Senegalese Agricultural Research Institute, ISRA), aimed to popularize new feed techniques and imported dairy breeds in order to create more intensive and specialized livestock systems. An experimental farm provided livestock feed and dairy cows, as well as zootechnical and veterinary supervision, while a cooperative was created to market milk in Dakar. The large majority of the new dairy farms did not survive after the project ended (Mbaye, 1989), but the intensive dairy production model persisted at a small scale.

\section{Structural adjustment and liberalization (1985-2000): the development of small-scale dairy processing}

During this period of progressive state withdrawal, several innovative initiatives were launched in dairy production, collection and processing. At the beginning of the 1990s, Nestlé developed a network to collect local milk in the pastoral areas surrounding the city of Dahra, a major national livestock market. Collected milk was dried and mixed with imported powdered milk in the Nestlé plant in Dakar. The operation's model of 
drying expensive collected milk made little economic sense, confirming suspicions that Nestlé's main goal was to promote a positive image of the company. It set up a network of collection centers to buy milk from hundreds of pastoralists. However, the quantities collected were generally low (82 000 liters in 1991 and 17000 liters in 1992, which was a drier year) and accounted for only 1 per cent of the factory's annual supply (Vatin, 1996: 168-169). Several factors explain the problems that Nestlé faced in collecting local milk: prices were higher in local informal markets, milk is a major source of nutrition for the calves, and the women controlling milk management sought to valorize both curdled milk and butter. The project ended in 2002 when Nestlé moved its factory abroad. 
In the mid-1990s, an alternative dairy processing pattern gained prominence in West Africa. With the support of the Food and Agriculture Organization of the United Nations (FAO) and non-governmental organizations, the number of mini-dairies processing local milk increased sharply ( 21 mini-dairies were operating in Senegal in 2000, 56 in 2010; Duteurtre and Corniaux, 2013: 33). Generally established in secondary cities, mini-dairies use basic equipment to collect and process small quantities of milk (from several tens to several hundreds of liters per day) to meet an urban demand for artisanal dairy products. Corniaux and al. (2005) identify the strengths but also the limits of such structures. Among their strong points, the authors mention local contracting with herders, and the provision of feed and veterinary inputs, sometimes on credit. Weaknesses include rapid saturation of local markets, supply difficulties during the dry season, and a minimal impact on national economies. In Senegal, the development of mini-dairies began with an innovative experiment in Casamance around the city of Kolda. From the middle of the 1980s, a public cotton company, Société de Développement des Fibres Textiles (Society for the Development of Textile Fibers, SODEFITEX), partnered with the ISRA to set up an incentive scheme for dairy production. This included the provision of subsidized livestock feed (cottonseed) on credit, as well as technical and veterinary support. From the beginning of the 1990s, the partnership was extended to include a French non-governmental organization Vétérinaires Sans Frontières (Veterinarians without Borders, VSF) which provided grants and technical assistance for the creation of a network of mini-dairies. Depicted as a success story in the 1990s, this initiative faced a crisis in the mid-2000s because of radical changes to the incentive scheme. Nevertheless, the dairy basin survived and a good dozen mini-dairies still collect local milk today.

At the end of the 1990s, the liberalization of trade between the West African Economic and Monetary Union (UEMOA) and external markets was implemented through a common tariff system for imports, enforced since 2000. This agreement established four tax rate thresholds: 0, 5, 10 and 20 per cent. Powdered milk was classed with raw materials and essential items and placed in the second threshold (5 per cent). As Duteurtre (2009) points out, common external tariffs were established before a common agricultural policy was developed. The extremely low tariffs for powdered milk imports reflected a political commitment in favour of the growing industrial processing sector and urban access to cheap products, at the expense of the coherence of sectoral development policies. 


\section{Recent trends (2000- ): a growing dynamic of "technicization" in dairy development public policy}

In 2000, the election of the liberal Abdoulaye Wade marked the beginning of a new phase in agricultural development policies. While the president claimed to use his strong executive power as a major driver of change, he promoted a liberal approach characterized by weak public intervention and delegation to the private sector.

Between 2000 and 2005, Senegalese dairy imports grew from 23 to 42 billion CFA francs ${ }^{2}$ (Duteurtre, 2009). In 2007/2008 an agricultural commodity price crisis demonstrated the dangers of this trend. Dairy prices increased sharply (imports grew to 83 billion CFA francs in 2013; Duteurtre and Corniaux, 2013), raising concerns about macroeconomic imbalances and urban consumers' access to dairy products. Rather than use this as an opportunity to reexamine patterns of dairy development, the government remained ambivalent. On one hand, a set of contingency measures were taken including tax exemptions for powdered milk imports and price controls. On the other, a program to improve national dairy production was devised by the government in 2008 , which combined classical technical elements (fodder crops, imports of dairy breeds, artificial insemination) with trade-related measures such as tax exemptions for production factors and the processing of local milk, as well as controls over the export of agricultural byproducts. However, the program was not funded and the more political propositions were not enacted. Only artificial insemination was effectively financed, and from 2008 to 2013 ran as an autonomous program of genetic improvement (Programme Spécial d'Insémination Artificielle Special Program of Artificial Insemination). The government presented this technical option as the best way to rapidly increase national milk production and reduce imports. The program also became a showcase for the presidential commitment to modernity and it clearly testifies to a growing "technicist" attitude in dairy development (Magnani, 2016: 143-158).

Since the 2000s, the dairy industry has experienced growth in the West African Sahel, where several dairy companies have started to collect local milk $^{3}$ (Duteurtre, 2007). A common trend towards mixing locally collected fresh milk and imported powdered milk emerged, which can be analysed as a new syncretic industrial

\footnotetext{
${ }^{2}$ The common currency in the UEMOA, 656 CFA francs $=1$ Euro.

${ }^{3}$ Eight companies are collecting local milk today: Eurolait and Mali-Lait (Mali), Kirène and Laiterie du Berger (Senegal), Tiviski (Mauritania), Solani and Niger-Lait (Niger), Fada N'Gourma (Burkina Faso).
} 
model (Corniaux et al., 2012). This allowed dairies to diversify their output and introduce higher value products (cream, cheese), and to more successfully manage the strong seasonal variability of local milk production. In Senegal, Laiterie du Berger (Shepherd's Dairy) opened its dairy plant in 2006 in Richard Toll and started to process milk collected from hundreds of pastoralists living in the hinterland of the Senegal River valley. In 2009, the dairy partnered with danone.communities, the foundation established by Danone multinational group, and started operating as a social business project.

The dairy landscape in Senegal shows signs of dynamism. Between 2000 and 2016 national production grew from 119 to 226 million liters, with $61 \%$ of output coming from pastoral and agropastoral systems, compared to an estimated demand of 457.5 million liters (Goudiaby and Broutin, 2018: 17-19). About thirty intensive dairy farms still operate around Dakar along with many others around the country's secondary cities. While the small-scale processing sector seems to be stable and even growing slightly in some regions (e.g. around Dahra and Linguère) (Seck and al. 2016: 9), dairy industrial processing has grown to include about fifteen companies. Among them, only two include local milk in their production: Laiterie du Berger and Siagro (Goudiaby and Broutin, 2018: 32). This dynamism reflects the significant gap between supply and demand which makes Senegal the fourth largest importer in Sub-Saharan Africa, excluding Sudan (Seck and al. 2016: $5)$.

While particularly evident in Senegal, this trend more broadly reflects the growing interest of multinational dairy groups in West African markets. While some companies have been present for decades (e.g. Nestlé, Lactalis), since the 2000s and in particular the 2010s, several other major dairy groups (Glanbia, Sodiaal, Danone, Friesland-Campina, Arla) have started joint ventures and made investments in West Africa (Choplin, 2016; Hansel and Goodison, 2015; Orasmaa et al., 2016). A number of key factors explain this tendency, including the regional gap between increasing dairy consumption and a stagnating supply, and the end of the European Union milk quota (2015), ${ }^{4}$ which saw dairy groups renew their search for new markets (CTA Agritrade, 2013, 2014). While the large majority of these initiatives rely on the processing or repackaging of

\footnotetext{
${ }^{4}$ The EU milk quotas were introduced in 1984 to avoid overproduction and price volatility. They were abolished in 2015 with the purpose of increasing European production and exports.
} 
imported powdered milk, many dairies have shown a willingness to include local milk in their supply chains, often as part of a social businesses or their corporate social responsibility (Corniaux, 2015). Several reasons can explain this trend: a desire to promote a positive image of the role that business plays in agricultural development (Binet, 2014), the diversification of supply sources, a move to more value-added products, and responses to governmental directives, as in the case of Friesland-Campina investments in Nigeria. In this sense, the current situation seems ambiguous with, on one hand, more opportunities for the industrial collection of local milk and, on the other, a trend of growing powdered milk imports fostered by a favorable tax system and increasing urban demand. While there is significant scope to expand local milk collection (60 dairies could potentially start processing local milk; Orasmaa et al., 2016: 29), a new boom in powdered milk imports risks not only discouraging local milk collection as well as national and regional dairy policy implementation, but also increasing competition with local dairy products, notably in secondary cities (Broutin and al. 2018; Hansel and Goodison, 2015; Orasmaa and al., 2016).

Within this context, national and regional dairy policy frameworks have a decisive role to play. However, the trajectory of dairy policy in Senegal reveals the extent of the challenge. As noted by Seck et al. (2016: 24), there has never been a structured dairy policy in the country. At present, dairy development appears to be a secondary goal in the livestock policy framework, namely the National Program for Livestock Development, which has a strong technical focus on animal health and genetics and aims to create 'modern' livestock farms with stabling of dairy cows. In the following section, we will show why acting only along technical lines is a reductive response to the challenges faced.

\section{Case studies analysis: patterns of dairy development and public action at work in Senegal}

\section{Dairy farming around Dakar: the failure of an industrial model disconnected from the processing sector}

Beginning in the mid-1970s, Senegalese public research on livestock development identified intensification and specialization of livestock systems in dairy production as ways to meet growing urban demand for dairy 
products (Denis, 1981). Two main drivers of intensification were highlighted: bovine genetics and livestock feed. A set of experiments were carried out to test exotic breeds' adaptation and performance, with encouraging results (Ba Diao, 1991). A balanced food ration using local resources was developed in the Sangalkam experimental farm and tested in the countryside. After this exploratory phase (1977-1982), a seven-year development project (Project for intensive and semi-intensive dairy development in the Niayes region) was implemented in the peri-urban area of Dakar (1982-1989). Several hundred imported Montbéliarde and Pakistani cows were delivered to 55 herders who also benefited from a range of services: subsidized animal feeds, technical and veterinary support, and artificial insemination. Despite these facilities, the project was a failure: due to the cows' mortality rate and the high production costs, 45 out of 55 farms collapsed within ten years. Researchers acknowledged that the model was ill-adapted to local livestock systems and economically unsustainable (Ba Diao, 2005: 98-105). Although the results were not positive, they could have been drawn on to devise new directions and long-term strategies. Instead, the project's failure put a definite end to public interventions in dairy development in the peri-urban area of Dakar.

Nevertheless, since the beginning of the 1990s, a few local businessmen have adopted the intensive livestock model (cow housing, imported specialized breeds fed with ensiled corn and industrial feeds) to build up largescale dairy farms. Three structures of this kind were still operating during our fieldwork. The socio-economic status and the origin of the owners had a strong impact on the trajectory of the farms. One owner was an important businessman operating in the oil trade. The other two were big import traders who had grown up in rural areas. These owners were largely motivated by the prestige of running a modern dairy business on a large scale (from 200 to 800 hundred cows) with exotic breeds (Holstein, Jersey, Normande and Girolando). But these features also contributed to the economic unsustainability of the projects. Significant investments in infrastructure were required because of the farms' size, while the management of large herds presented difficulties in terms of animal feeding, health and reproduction. A lack of access to land and available water limited the production of forage crops, encouraging the use of expensive concentrated feeds ${ }^{5}$. Exotic breeds were sensitive to diseases and poor habitat conditions, particularly during the wet season. As a result of these difficulties, at best only a third of the "productive" herds were lactating dairy cows. Production costs of milk

\footnotetext{
${ }^{5}$ In 2014, $40 \mathrm{~kg}$ of industrial feed for dairy cows cost 7600 CFA francs.
} 
(approximately $350 \mathrm{CFA}$ francs on average per liter) were thus high, discouraging industrial processors from including it in their supply ${ }^{6}$. Raw and curdled milk were sold through a network of hundreds of independent sellers who bought only a few tens of liters each and were therefore unable to absorb the total daily production of a farm (from 700 min. to 3000 liters max. per day depending on the season and the farm). In order to valorize their surplus output, farmers had to invest in expensive infrastructure to cool and process milk for sale on the formal urban market, where farm fresh curdled milk and yogurts were in direct competition with the cheaper powdered milk products. As a result, the processing experiment was a major failure that reinforced the farms' dependence on the unconditional economic support of their wealthy owners.

In the 2000s, a pool of smaller farms (10 to 50 dairy cows) emerged in the countryside around Dakar. During our fieldwork we monitored six of these structures to compare their performance, technical models and social organization. The social profiles of owners were diverse (three traders, a veterinarian, an army colonel) but only one, a French herder, had relevant experience in dairy farming. They were generally cautious towards investment compared to the owners of the large farms. Small farms needed less capital for infrastructure and their low quantities of milk (from 100 min. to 500 liters max. per day depending on the season and the farm) were easier to sell directly on farms or in local shops. However, these small farms faced the same challenges in terms of high production costs and a lack of access to land and water. As a result, only two of the six farms were able to make a profit (Magnani, 2016: 191). These two farms shared several characteristics. Firstly, they had good access to profitable niche markets: one was selling dairy products on demand to a network of expatriate clients, the other commercialized different products (fruit, eggs, chicken, fresh and curdled milk) in a grocery in Dakar. Secondly, they opted for small herds of around fifteen Holstein cows acclimated over generations. Thirdly, the owners were working full-time on the farm and brought knowledge and pragmatism. Cows were allowed to graze on small pastures in order to keep the stables clean and improve habitat conditions. The cows' health was closely monitored.

In conclusion, the dairy livestock systems studied around Dakar were 'intensive' in inputs, capital and workload but most of them seemed to lack a sustainable economic model, partly because of the social origins of the investors. But the economic climate was also particularly difficult: a lack of integration with the processing

\footnotetext{
${ }^{6}$ In 2013, only one industrial dairy was buying 6000 liters of milk per week, from a big farm at 400 CFA francs/liter.
} 
sector; high input prices; limited access to land in the face of uncontrolled urbanization; strong competition from powdered milk. In such conditions, intensive systems needed a high level of technical support and connections to niche markets to survive.

\section{The dairy basin of Kolda: the successes and crises of a development model based on agriculture - livestock integration}

The dairy basin around the city of Kolda in southern Senegal was created at the beginning of the 1990s, through a partnership between a public cotton industry (SODEFITEX) and the Senegalese Agricultural Research (ISRA). SODEFITEX saw dairy development as a way to increase farmers' incomes and encourage them to grow cotton. The technical reference was the integration of agriculture and cattle herding, in a region with one of Senegal's largest cattle populations (599 000 head as of 2007) ${ }^{7}$. This model relied on the local breed Ndama, a poor dairy but trypanotolerant breed, well adapted to the local sub-humid climate. Grants were allocated to Fulani agro-pastoralists ${ }^{8}$ to build cattle barns to house milking cows during the dry season. A range of attractive services were also provided to sustain dairy production: subsidized cottonseed ${ }^{9}$ as supplementary feed and credit from SODEFITEX; technical and veterinarian support from research and development public services. With the support of these measures, the number of dairy barns grew quickly to 1000 in 1992 (Fall and Faye, 1992: 7). In order to process the increasing volume of milk produced, a non-governmental organization, Veterinarians without borders (VSF), funded the creation of a mini-dairy processing sector (five mini-dairies were operating in 2000). Progressively, the dairy sector grew to include producers, processors, private collectors and service providers working within a radius of $25 \mathrm{~km}$ around Kolda.

At the end of the 1990s, the public action scheme for dairy development was fundamentally reorganized. SODEFITEX gave up its role as financial backer and was replaced by the Swiss Cooperation, which created a Service Center in partnership with the ISRA in research and innovation, and with SODEFITEX and VSF in

\footnotetext{
${ }^{7}$ Source: Senegalese National Agency of Statistical and Demographic Data.

${ }^{8}$ In the region most of the rural population engage in crop and livestock farming, though practices vary depending on their socio-cultural identity and the history of their social groups, which influence land tenure dynamics and economic activities.

${ }^{9}$ Cottonseed was initially given free of charge. A price was fixed at 15 CFA francs per kilo in 1992 and increased to 50 CFA francs in 1996.
} 
offering support to livestock farmers and dairy processors. The aim was to provide services on demand to herders and to the dairy processors, who would progressively assume the costs. Researchers attested to the profitability of dairy production at this time (Dieye and al., 2003) and eight mini-dairies processed 208105 liters of local milk, a record quantity, in 2004 (Faye and al., 2005). Up to 2005, the Kolda dairy basin was considered a successful experiment based on the improvement of cattle feed through a combination of protein supplements (cottonseed) and local agricultural residues and natural pastures. However the following years saw radical change that led to the Service Center being closed and the dairy basin facing a major crisis. The main factor was the privatization of the cotton company in 2003, following which the interest-free loan scheme for cottonseed was abolished in 2005 , leading to milk shortages in the dairy basin. At the same time, SODEFITEX unilaterally started to collect milk in more distant areas and to sell it to Kolda mini-dairies to make up for shortfalls in supply. This produced tensions both between herders and mini-dairies, and between SODEFITEX and its partners in the service center. The partnership was thus ended in 2006 and Swiss development funds were cut. The subsequent phase of the project, which should have seen the transfer of the incentive scheme to local professional organizations, was never implemented. Finally, in 2007, SODEFITEX sharply increased cottonseed prices from 50 to 122 CFA francs per kilo. As a result of all these factors, milk became extremely scarce during the dry season between 2006 and 2010 and mini-dairies were forced to process powdered milk.

From 2011 onwards, the situation began to improve because of the intervention of several non-governmental organizations, as well as decentralized foreign cooperation that replicated the technical scheme developed by SODEFITEX and the ISRA on a gift basis with little or no coordination. This sustained dairy production and supply to mini-diaries (12 operating in 2013) but was not designed to solve the structural constraints of the dairy basin. Rather, interventions exacerbated problems for several reasons. Firstly, gifts of cottonseed stocks encouraged neither durable solutions to supply problems nor the development of local institutions to obtain feed regularly on credit. Secondly, poor coordination among developers exacerbated both opportunistic strategies (little incentive to repay loans and mutualize funds) and dynamics of competition and patronage between outsiders (non-governmental organizations, decentralized cooperation) and local actors (professional organizations, decentralized public institutions). Local actors depended on outsiders for access to international aid, while the same outside groups needed clients to raise funds from donors. In short, the "logic of gift" met 
the short-term performance requirements of the projects and maintained dependency relationships but was a major obstacle to promoting real autonomy for local actors.

Despite all this, local herders successfully adopted protein supplementary feeds as a means to develop complementarity between agriculture and cattle-herding and so produce milk throughout the year. During our fieldwork, milk production with the Ndama breed was still considered an attractive option in the peri-urban area, despite high cottonseed prices (150 CFA francs/kg in 2013). In fact, an increase in cattle fertility and the improved health of both cows and calves were cited as the principal benefits of supplementing feed for milking cows during the dry season, rather than the income generated by milk sales (Magnani, 2016: 217-224).

\section{The dairy basin of Richard Toll: a classical intensification scheme to improve production in pastoral}

\section{systems}

In 2006, a dairy factory, Laiterie du Berger (Shepherd's Dairy, LdB), was set up in Richard Toll, in the Senegal River valley. The city is home to Senegal's most important agro-industry, namely growing and processing sugar cane. The dairy factory was supplied with milk collected from hundreds of pastoralists living in the close hinterland of the valley (35 $\mathrm{km}$ around the city).

Between 2006 and 2008, the dairy factory exclusively processed local milk and targeted a niche market of upper class urban and expatriate consumers. During this period, the dairy faced severe economic difficulties due to the low volumes collected ${ }^{10}$. In 2008 , thanks to the innovative character of the initiative, the dairy was able to form an alliance with danone.communities, which provided LdB with expertise in strategic areas such as manufacturing, marketing and distribution of dairy products. The partnership attracted private and public backers that invested in the dairy and in its collection basin ${ }^{11}$. Powdered milk was included in the supply, particularly during the dry season, to ensure that factory production met consumer demand throughout the year.

\footnotetext{
${ }^{10}$ In 2007, the dairy collected on average 1066 liters/day, compared to the plant's processing capacity of 10000 liters/day.

${ }^{11}$ Partners were: Danone and danone.communities, CSS Senegalese Sugar Company, Crédit Agricole Grameen Bank, public donor agencies (Coopération de Monaco - Monaco Cooperation, Agence Française de Développement - French Aid Agency - (AFD)) and a French non-governmental organization (GRET). Research institutions monitor its dynamics: International Livestock Research Institute (ILRI), French Agricultural Research for Development - (CIRAD), International Food Policy Research Institute (IFPRI).
} 
The creation of a successful brand led to a significant increase in the volume of sales ${ }^{12}$. Following this commercial success, new directives were issued regarding the milk collection service.

From 2011, management stressed the need to stabilize milk collection, which was strongly affected by seasonality and pastoral mobility in the arid environment. In order to reduce collection costs, LdB officials tried to convince pastoralists to settle their milking cows during the dry season. They set up a credit scheme to promote the systematic use of industrial feeds and sugar cane residues, with the support of the sugar cane industry (Compagnie Sucrière Sénégalaise - Senegalese Sugar Company), a strategic ally of LdB, which has historically had tense relations with pastoralists because of land expropriation. As shown by our research, the dairy failed to significantly reduce the variability, both seasonal and annual, of pastoral milk production, which was dependent on the highly variable quality and quantity of natural pastures. In fact, the change envisioned by the industrialists was in several ways inconsistent with the practices of the pastoralists, who sought to take advantage of new commercial opportunities during the rainy season, when selling milk to the factory was extremely advantageous. At such times, dairy production was abundant because of fresh pastures and inputs were not required. In contrast, during the dry season, milk sales were less profitable or indeed unprofitable for pastoralists. The speed at which pastures were consumed depended on the quality of the previous rainy season, and once they were exhausted milk sale revenues failed to cover the cost of the input needed to feed dairy cows. Some herders kept some milking cows at their camps for dairy collection, while moving the rest of the herd in search of water and pastures, for a number of different strategic reasons. Firstly, those herders facilitated the mobility of the herd by stabilizing the elderly people and children, while ensuring their access to milk. Secondly, they secured access to animal feeds on a credit basis, which was particularly important in case of drought. Thirdly, they acted to ensure rainy season milk sales, as the dairy factory prioritized the herders who supplied milk on a continuous basis. In fact, while the industrialists tried to induce a relative specialization in dairy production and to encourage the use of animal feeds, pastoralists promoted the multi-functionality of their systems and tried to limit the use of the expensive inputs (Magnani, 2016: 258-274).

$121140 \mathrm{t}$ in 2011 , compared with $430 \mathrm{t}$ in 2007. 
From a broader perspective, a focus on livestock system intensification ignored patterns of change in local natural resource management. Historically, Fulani pastoralists enjoyed seasonal access to the Senegal River valley. They spent the rainy season in the hinterland, watering livestock in ponds and feeding them with fresh grass. At the beginning of the dry season they moved to the river valley, following the flood-recession agriculture techniques practiced by peasants and using pastures available in the depressions flooded by the river (Touré and Arpaillange, 1986). This system, which relied on complementarity between both agriculture and pastoralism, and dry and flooded areas, gave pastoralists access to valuable feeding pastures for cattle during both the dry and rainy seasons. From the 1950s, development interventions brought major changes in agricultural and pastoral systems. The first driver of change was the construction of a dense network of boreholes in the hinterland, which made water available throughout the year and encouraged pastoralists to settle around them. This compromised the rules governing access to grasslands in the hinterland (Barral, 1982). The second major driver of change was the development of the Senegal River valley as an exclusive space for irrigated agriculture. Between the 1980s and the 1990s, pastoralists were progressively excluded from the resources of the humid zone (Santoir, 1994) and became more dependent on the highly variable pastures of the dry hinterland in which they were settled. Transhumance in the valley during the dry season was replaced by scattered movements following the progressive depletion of pastures around the boreholes. As a consequence, pastoralists started to use expensive animal feeds to compensate for the decline in the quality of pastures and their highly variable availability from year to year.

These changes in access to resources and pastoral practices are crucial to understanding why producing milk during the dry season is now difficult and costly for pastoralists. But the main contradiction underlying LdB's social business is that its major partner in the dairy intensification scheme, CSS Sugar Company, has been, and still remains, a central actor in development interventions and natural resource management patterns in the area. Since the mid-1970s, CSS has grown sugar cane on around 10000 ha of irrigated land between Richard Toll and Lake Guiers. Since 2010, in order to increase sugar production, the company has appropriated several thousand more hectares of pastoral land, this time directly in the hinterland of Richard Toll.

In any case, with the support of its partners, LdB grew quickly and within a few years became Senegal's second largest dairy company, with commercialized volumes reaching $2200 \mathrm{t}$ in 2013 . Though the social business 
image of the company was built on the collection of milk among pastoralists, the record sales and strong increase in production were mostly due to imported powdered milk. The latter accounted for at least half of LdB's production between 2012 and $2014^{13}$.

\section{Discussion: looking beyond technical dimensions}

The analysis of these case studies shows the urgent need to overcome a technical approach in public policy on dairy development. In fact, our research shows that political, economic and social dimensions play an overwhelming role in all the situations under analysis.

Around Dakar, an industrial dairy production model was directly transferred from Western countries without any integration envisaged with local livestock systems, breeds, skills or resources. It was hoped that the model would spread as more businesses sought to imitate it and became willing to invest. But dairy farms were disconnected from the industrial processing sector and their product was in direct competition with imported tax-free powdered milk. Moreover, the artificialization of production systems failed: animals were suffering because of badly adapted installations and feed rations; their milk production was variable and costly. In the absence of a solid professional culture and a coherent, incentivized, long-term policy framework, the hope that an intensive dairy production model would become widespread remained unrealistic. All in all, public research was undertaken for fifteen years, mainly in experimental stations, and supportive public initiatives were implemented only for seven years. In fact, technicizing the challenges of dairy development in this context ignores the centrality of social organization, production and marketing constraints, as well as the absence of incentives for local dairy production and processing. Indeed, a professional organization representing dairy farmers has unsuccessfully called on the government for measures including the preservation of agricultural land around Dakar, tax incentives for investments in local milk processing and production, the inclusion of local dairy products in school canteens and support for setting up farms.

The Kolda case study illustrates how policy frameworks can be a double-edged sword that leads to the emergence of a dairy basin as well as to its progressive disruption. A holistic public support framework was successfully implemented in the dairy basin of Kolda for around two decades, thanks to the partnership between

\footnotetext{
${ }^{13}$ Source: LdB, 2014.
} 
two public institutions with a development mandate. Its temporary success depended on the provision of essential services: access to feeds under preferential terms, coordination among stakeholders, and technical assistance. This ended with the privatization of the cotton company and the dismantling of public development services as a result of the liberalization of the agricultural sector, creating an institutionalized dependency on international aid. The attempt to replace public interventions with a service center financed by a foreign cooperation agency failed because of the conflicting and opportunistic behavior of the institutions involved. In fact, cooperation among partners was impossible in the absence of a policy framework supervising and organizing private aid interventions. The scaling down of public support to non-governmental organizations from the middle of the 2000s saw the dairy sector destructured. Competition among development actors, a short-termist approach to projects and performance requirements, clientelistic relations and the co-optation of local organizations discouraged collective action and organization in the dairy basin. As a consequence, it is now regarded by national authorities and development organizations as a problematic example of dependency and a lack of local expertise. Nevertheless, the dairy basin still exists and seems to be an appropriate response to the needs of a landlocked city like Kolda as well as to herders' constraints.

The third case study, examining the LdB dairy basin, is often referred to as a success story in the regional academic and institutional literature on poverty-focused rural development (Wane and al., 2014). Its high-risk approach to the challenges of fresh milk supply in drylands gained support and interest from several donors and partners in the name of social business. This type of operation is part of a new two-way development model. On one hand, partners' statements are consistent with the notions of inclusive growth and markets, promising increased profit through a business meeting the needs of the poor (Arnani, 2006; Binet, 2014; Gradl and al., 2008). On the other, LdB dairy consortium is archetypical of a modern intervention in development, whereby public funds are used to directly support private investments (Gabas and al., 2014). Though presented as part of the social business movement, the technical intensification pattern promoted by LdB ignores fundamental changes in local economy and society generated by a set of development interventions. Pastoralists have shown that they have valid economic and ecological reasons to resist a further intensification of their systems. Through its alliance with a major actor of the local agribusiness, the dairy project, while appearing to be an innovative 
and socially oriented initiative, legitimizes contemporary and historical trends of land grabbing in grassland areas.

Thus, it would be unwise to base dairy policy on the expected generalization of this specific case, even though this model of local milk collection offers several opportunities for pastoralists. Whatever the future of the LdB dairy project, it challenges the political framework in which a private-foundation-aid system is responsible for providing support for local livestock development and the supply of dairy products to the urban market. If such fragmented and poorly coordinated interventions were to become standard in Senegal, as in other sub-Saharan countries heavily dependent on aid, it would increase uncertainty about the state's capacity to regulate food policy and to deliver basic goods and services to their population.

\section{Conclusion}

The article demonstrates that focusing and acting mainly on technical issues of dairy development has two main implications. Firstly, it overlooks the political choices and economic conditions that hinder the development of local dairy production in West Africa, namely the competition of powdered milk which remains tax-free, and the lack of a framework of public policies to support the production and processing of milk. Secondly, it ignores the relationships between the herders, their environment, markets, livestock and social dynamics.

The case studies offer different examples of how local livestock production systems are either plainly ignored or required to change with limited regard for their own constraints and strategies. At present, Senegal is still lacking a comprehensive and coherent dairy policy. Within the current policy framework, the artificialization of livestock systems, a central goal of the dominant technical paradigm, has little or no chance of working. Intensive dairy systems, developed without regard to their environment, need easy access not only to feeding inputs, but also to the equipment and technical knowledge necessary to run a specialized dairy system. This would require price controls and protective tariffs, negotiated in a regional economic space where West African states should be able to stimulate global production by promoting regional complementarities. Given the high level of risk involved in working with local milk, the investment it demands and the large availability of powdered milk, achieving a balance more favorable to local dairy development will require the political commitment of national governments and regional institutions to implement coherent dairy, livestock and 
commercial policies. This policy framework should include measures for the improvement of local milk production (incentives, assistance, adapted territorial development schemes), collection and processing (infrastructure facilities, fiscal incentives) as well as progressive regulations discouraging the simple repackaging of powdered milk, improving transparency around powder qualities, introducing local sourcing requirements for dairy processors and increasing tariffs for powdered milk imports. Most serious actors in the Senegalese and regional dairy sector, including the main regional professional organisation networks and a number of NGOs and research organisations, actively campaign for a more comprehensive policy framework such as this, but still receive little attention from public authorities.

Some initiatives look promising in this regard, such as the "regional offensive for the promotion of local milk in West Africa' currently being drafted within the Economic Community of West African States (ECOWAS), or the announcement by the Senegalese government that it will consider tax exemptions for the processing of local milk. Nevertheless, the outcome of such processes remains unclear: ECOWAS is having difficulty in finding funds and the proposed tax exemptions have not yet been scheduled. Furthermore, the Economic Partnership Agreements being negotiated between the European Union and ECOWAS could be a major obstacle to the implementation of any sectoral regulation in the future. This regional free trade agreement provides for the complete liberalisation of the import of powdered milk (in $25 \mathrm{~kg}$ bags) within five years of its implementation and requires EU approval of any future revision of custom tariffs.

In any case, a more realistic dairy policy should be based on a better understanding of, and improved support for, local livestock systems in all their diversity. A policy building on local knowledge, practices and social organization to encourage productive interactions between livestock systems and environment could help to develop and support alternative production systems. This could be a more effective answer to the challenges of rural and livestock development and urban consumption, as well as a coherent way to promote food sovereignty in Senegal and West Africa.

\section{Acknowledgements}

This article has stemmed from a paper presented at the « 2015 World Food Policy Conference, The Future Faces of Food and Farming » $\left(17^{\text {th }}-18^{\text {th }}\right.$ of December 2015, Bangkok, Thailand). We express our gratitude to 
the French National Research Agency (ANR) and French Agricultural Research and International Cooperation Organization (CIRAD) for their financial support.

\section{Conflict of interest statement}

On behalf of all authors, the corresponding author states that there is no conflict of interest.

\section{$\underline{\text { References }}$}

Arnani, A.G. (2006) Mirage at the Bottom of the Pyramid. How the private sector can help alleviate poverty. William Davidson Institute, Working Paper Number 835. University of Michigan.

Ba Diao, M. (1991) Les systèmes d'élevage dans la Région des Niayes du Sénégal. II L'élevage laitier intensif. [Livestock Systems in the Niayes Region, Senegal. II Intensive Dairy Farming]. Dakar, ISRA.

Ba Diao, M. (2005) Situation et conditions de développement de la production laitière intensive dans les Niayes au Sénégal. [Situation and Conditions of the Development of Intensive Dairy Production in the Niayes, Senegal]. PhD Thesis, UCAD, Dakar.

Barral, H. (1982) Le Ferlo des forages. Gestion actuelle et ancienne de l'espace pastoral. [The Ferlo of Boreholes. Past and Present Management of the Pastoral Space]. Dakar, ORSTOM.

Behnke, R.H., and Scoones, I. (1993) Rethinking range ecology: implications for rangeland management in Africa. In R.H. Behnke, I. Scoones, and K. Kerven (eds.) Range ecology at disequilibrium: New models of Natural Variability and Pastoral Adaptation in African Savannas. London, ODI.

Binet, N. (2014) Le rôle des entreprises et des fondations privées dans la gouvernance mondiale agricole et alimentaire. [The Role of Private Businesses and Foundations in the Global Governance of Agriculture and Food]. Mondes en développement 165 (1): 23-36.

Broutin, C., and Goudiaby, M.C. (2018) Quelles politiques commerciales pour la promotion de la filière « lait local » en Afrique de l'Ouest? - Rapport Sénégal [What Trade Policy to Promote Local Dairy Value-Chains in West Africa? - Report Senegal]. Paris, GRET.

Broutin, C., Lévard, L., and Goudiaby, M.C. (2018) Quelles politiques commerciales pour la promotion de la filière « lait local » en Afrique de l'Ouest [What Trade Policy to Promote Local Dairy Value-Chains in West Africa ?]. Paris, GRET.

Corniaux, C. (2015) L'industrie laitière en Afrique de l'Ouest : Histoire, Stratégies, Perspectives. [The Dairy Industry in West Africa: History, Strategies, Perspectives]. Project “Milky Way for Development.” Dakar, CIRAD.

Corniaux, C., Duteurtre, G., Dieye, P.N., and Poccard Chapuis, R. (2005) Les minilaiteries comme modèle d'organisation des filières laitières en Afrique de l'Ouest : succès et limites. [Mini-dairies as a Model of Organization of Dairy Value-chains in West Africa: Successes and Limits]. Revue d'Élevage et de Médecine Vétérinaire des Pays Tropicaux, 58 (4) : p. 237-243.

Corniaux, C., Vatin, F. and Ancey, V. (2012) Lait en poudre importé versus production locale en Afrique de l'Ouest: vers un nouveau modèle industriel? [Powdered milk Versus Local Dairy Production in West Africa: Towards a New Industrial Model?]. Cahiers agricultures 21 (1): 18-24.

Centre Technique de coopération Agricole et rurale (CTA Agritrade). (2013) End of dairy Quotas leads to greater external Focus of EU dairy Companies. 
Centre Technique de coopération Agricole et rurale (CTA Agritrade). (2014) Le commerce laitier entre l'UE et l'Afrique évolue: réponses des entreprises européennes à l'abolition des quotas de production de lait. [The Dairy Trade between the EU and Africa evolves: European Dairies Respond to the End of Dairy Quotas].

Choplin, G. (2016) L'industrie laitière européenne lorgne sur l'Afrique de l'ouest. [The European Dairy Industry is Eyeing West Africa]. Oxfam-Solidarité, SOS Faim Bélgique.

Denis, J.P. (1981) Promotion laitière chez les Paysans du Cap-Vert. [Dairy Promotion among the Farmers of Cape Verde]. Paper presented at the conference, Les contraintes dans l'intensification des productions animales au Sénégal et les essais de solution, 24-26 mars 1981. Dakar, ISRA.

Dieye, P.N., Duteurtre, G., Sissokho, M.M., Sall, M. and Dia, D. (2003) La production laitière périurbaine au sud du Sénégal. Saisonnalité de l'offre et performances économiques. [Peri-urban Dairy Production in Southern Senegal. Seasonality and Economic Performances]. Tropicultura, 2003, 3: 142-148.

Duteurtre, G. (2007) Commerce et développement de l'élevage laitier en Afrique de l'Ouest - une synthèse. [Trade and Development of Dairy Farming in West Africa - An Overview]. Revue d'Élevage et de Médecine Vétérinaire des Pays Tropicaux, 60: 209-23.

Duteurtre, G. (2009) Lait des pauvres, lait des riches : réflexion sur l'inégalité des règles du commerce international. [Milk for the Poor, Milk for the Rich: Reflections on International Trade Inequalities]. In DUTEURTRE, Guillaume and Bernard FAYE (eds), L'élevage, richesse des pauvres. Editions Quae.

Duteurtre, G. and Corniaux, C. (2013) Etude relative à la formulation d'un Plan d'actions détaillé de développement de la filière lait au sein de l'UEMOA. [Study for the Formulation of a Detailed Development Plan for the Dairy Value-chain in the West African Economic and Monetary Union]. CIRAD/UEMOA.

Ellis, J.E., and Swift. D.M. (1988) Stability of African pastoral ecosystems: Alternate paradigms and implications for development. Journal of Range Management 41 (6).

Fall, A. and Faye, A. (1992) Les étables fumières en zone d'élevage de bétail trypanotolérant au Sud du Sénégal. [Manure Barns in Trypanotolerant Herding Zones in Southern Senegal]. Dakar, ISRA/FAO.

Faye, A., Mbaye, A. and Mivelaz, J. (2005) Développer des synergies entre les services agricoles pour promouvoir la transformation des agricultures familiales : L'expérience du Pôle de Services au Sud-Est du Sénégal. [Developing Synergies among Agricultural Services to Promote the Transformation of Family Farming: The Experience of the Service Centre in South Eastern Senegal]. Paper presented at the Conference, Xème Journées d'Etudes Ingénierie des dispositifs de Formation à l'International, Montpellier, Agropolis International, December 8-9.

Gabas, J.J., Pesche, D., Ribier, V., and Campbell, B. (2014) Nouveaux regards sur la coopération pour le développement et ses transformations. [New Perspectives on the Cooperation in Development and its Transformations]. Mondes en développement 165 (1): 7-22.

Gradl, C., Sobhani, S., Bootsman, A., and Gasnier, A. (2008) Understanding the markets of the poor: A market system approach to inclusive business models. In Sustainability challenges and solutions at the base of the pyramid: Business, technology and the poor, edited by Minna Halme and Prabhu Kandachar, 29-50. Greenleaf Publishing/GSE Research.

Hansel, M.E., Goodison, P. (2015) Beyond the Milking Parlour: An Analysis of European Dairy Company Involvement and Strategies towards West African Dairy Sector Development. Project “Milky Way to development."

Homewood, K. (2008) Ecology of African Pastoralist Societies. James Currey, Ohio University Press, UNISA Press. 
Hubert, B. and Ison, R. (2011) Institutionalising understandings: from resource sufficiency to functional integrity. In Kammili, Trish, Bernard Hubert, and Jean-François Tourrand (eds.) A paradigm shift in livestock management: form resource sufficiency to functional integrity. Lirac, Cardère publishing.

Magnani, S. (2016) Le Lait local au Sénégal : Intensifier pour développer? Dynamiques socio-techniques et Anthropologie des pratiques. [Local Milk in Senegal: Intensification for Development? Socio-technical Dynamics and Anthropology of Practices]. PHD Thesis, Marseille: EHESS, p. 392.

Mbaye, M. (1989) Analyse du projet de développement de la production laitière bovine intensive et semi-intensive des Niayes. [Analysis of the Development Project of Intensive and Semi-intensive Dairy Production in the Niayes]. Dakar, ISRA.

OCDE/FAO (2017) Produits laitiers, [Dairy Products]. In Perspectives agricoles de l'OCDE et de la FAO 20172026. OCDE, Paris.

Orasmaa, T., Duteurtre, G. and Corniaux, C. (2016) The end of EU Milk Quotas - Implications in West Africa. Project "Milky Way to Development." Montpellier, CIRAD.

Santoir, C. (1994) Décadence et résistance du pastoralisme. Les Peuls de la vallée du fleuve Sénégal. [The Decline and Resistance of Pastoralism. The Fulani of the Senegal River Valley]. Cahiers d'Etudes Africaines 34 (133-135): 231-263.

Scoones I. (ed.) (1994) Living with uncertainty. New directions in pastoral development in Africa. London: Intermediate Technology Publications, IIED.

Seck, M., Marshall, K and Fadiga, M.L. 2016. Policy framework for dairy development in Senegal. Nairobi, Kenya: ILRI.

Touré, O. and Arpaillange, J. (1986) Peul du Ferlo. [Fulani of the Ferlo] Paris, L'Harmattan.

Vatin, F. (1996) Le lait et la raison marchande. Essais de sociologie économique. [Milk and the Market Rationale. An Essay of Economic Sociology]. Presses universitaires de Rennes.

Wane, A., Cadilhon, J.J., and Yauck, M. (2014) Food security and nutrition as basic indicators of socioeconomic sustainability in a context of innovation. The case of the Laiterie du Berger (LDB) in Senegal. Nairobi, ILRI. 